\title{
Relaksasi Napas Dalam: Jurnal Refleksi
}

\section{FEBRI WARNI HULU}

febriwarnihulu@gmail.com

Puji syukur saya ucapkan kepada Tuhan Yang Maha Esa, dimana karena berkat dan kasihnya saya mampu melakukan terapi Tarik napas dalam pada pasien. Awalnya saya sangat ragu dengan terapi ini, saya takut akan gagal, apalagi ini dengan pasien yang memiliki masalah gangguan jiwa. Namun setelah saya aplikasikan terhadap beberapa pasien, saya berhasil melakukannya dengan baik. Emosi serta kecemasan pasien berkurang. Saya menerapkan terapi ini pada pasien risiko perilaku kekerasaan, pasien merupakan laki-laki usia 20 tahun. Pasien memiliki riwayat menggunakan obat terlarang. Kondisi pasien saat ini pasien merasa dia tidak dihargai, dia berkata bahwa dia ingin keluar karena dia sudah bebas. Saat dikaji, pasien mengatakan bahwa dia ditinggalkan nikah oleh kekasihnya.

Risiko perilaku kekerasan ini jika tidak segera ditangani maka akan membahayakan diri pasien sendiri dan juga orang lain. Perilaku kekerasan adalah suatu keadaan yang mengeskpresikan perasaan marah, takut atau ketidakberdayaan terhadap situasi. Gejala kognitif perilaku kekerasan seperti ditemui adanya bingung, supresi pikiran, tidak mampu memecahkan masalah dan gangguan penilaian. (Sutinah 2019). Seseorang yang mengalami perilaku kekerasan sering menunjukkan perubahan perilaku seperti intonasi suara keras, mengancam, ekspresi tegang, gaduh, gelisah, tidak bisa diam, mondar-mandir, agresif, bicara dengan semangat, nada suara tinggi dan gembira berlebihan. Kekacauan alam fikir juga dapat dilihat dari isi pembicaraannya. Perubahan lain yang terjadi adalah adanya penurunan kemampuan 
memecahkan masalah, orientasi terhadap waktu, tempat, dan orang, serta gelisah. (Pardede, 2020)

Tarik Napas Dalam merupakan salah satu intervensi dalam menangani pasien dengan risiko perilaku kekerasan. Teknik relaksasi nafas dalam dapat mengatur emosi dan menjaga keseimbangan emosi, sehingga emosi marah tidak berlebihan. Relaksasi nafas dalam dipercaya dapat menurunkan ketegangan dan dapat memberikan ketenangan. Relaksasi nafas dalam merangsang tubuh untuk melepaskan opiod endogen (Sutinah, 2019).

Terapi ini saya terapkan pada pasien yang mengalami masalah keperawatan jiwa yaitu risiko perilaku kekerasan. Tindakan ini memberi efek positif pada klien, yang awalnya klien mudah marah dan selalu berbicara dengan nada tinggi, sekarang pasien nampak bisa mengendalikan dirinya. Awalnya pasien berkata bahwa itu semua tidak berguna, dan dia tidak mau melakukannya, namu saya terus mencoba menjelaskan dan melatih pasien. Pasien awalnya selalu mudah tersinggung dan setiap berbicara selalu dengan nada tinggi, dia selalu marah saat disuruh minum obat dan saat berjumpa dengan perawat, bahkan dia pernah memaki kakak perawat yang sedang memberi obat kepadanya, namun setelah saya mengajarkan pasien cara mengontrol perilaku kekerasan dengan Tarik napas dalam, sekarang dia mulai tersenyum dan mampu menahan dirinya dari amarahnya. Kadang dia juga membantu memanggil temannya saat disuruh minum obat. Meski begitu pasien berkata kadang tidak dapat menahan diri saat ada hal yang membuat nya marah. Saya bangga sekali dapat melakukan terapi ini, saya berharap semoga ilmu yang saya dapat ini menjadi bekal yang berharga bagi saya kedepannya. 


\section{Daftar Pustaka}

1. Sutinah, S., Safitri, R., \& Saswati, N. (2019). Teknik Relaksasi Nafas Dalam Berpengaruh Terhadap Kemampuan Mengontrol Marah Klien Skizofrenia. Journal Of Healthcare Technology And Medicine, 5(1), 45-55.

2. Sudia, B. T. (2021). Aplikasi Terapi Relaksasi Nafas Dalam terhadap Pengontrolan Marah dengan Pasien Gangguan Jiwa Resiko Perilaku Kekerasan di Wilayah Desa Maleber Kabupaten Cianjur. Lentera: Jurnal Ilmiah Kesehatan dan Keperawatan, 4(1), 1-5.

3. Pardede, J. A., Siregar, L. M., \& Halawa, M. (2020). Beban dengan Koping Keluarga Saat Merawat Pasien Skizofrenia yang Mengalami Perilaku Kekerasan. Jurnal Kesehatan, 11(2), 189-196. 